\title{
Ellagic acid suppresses oxidised low-density lipoprotein-induced aortic smooth muscle cell proliferation: studies on the activation of extracellular signal-regulated kinase $1 / 2$ and proliferating cell nuclear antigen expression
}

\author{
Weng-Cheng Chang ${ }^{1}$, Ya-Mei $\mathrm{Yu}^{1}$, Su-Yin Chiang ${ }^{2}$ and Chiung-Yao Tseng ${ }^{3}$ \\ ${ }^{1}$ Department of Health Sciences, Chang Jung Christian University, 396 Chang Jung Road, Sec. 1 Kway Jen, Tainan, Taiwan \\ ${ }^{2}$ Institute of Chinese Medical Science and ${ }^{3}$ Institute of Medical Science, China Medical University, Taichung, Taiwan
}

(Received 9 March 2007 - Revised 30 July 2007 - Accepted 30 July 2007)

Proliferation of intimal vascular smooth muscle cells is an important component in the development of atherosclerosis. Ellagic acid is a phenolic compound present in fruits (raspberries, blueberries, strawberries) and walnuts. The present study investigated the effect of ellagic acid on the oxidised LDL (ox-LDL)-induced proliferation of rat aortic smooth muscle cells (RASMC). The study found that ellagic acid significantly inhibited ox-LDL-induced proliferation of RASMC and phosphorylation of extracellular signal-regulated kinase (ERK) 1/2.Furthermore, ellagic acid also blocked the ox-LDL-induced (inducible) cell-cycle progression and down regulation of the expression of proliferating cell nuclear antigen (PCNA) in RASMC. Therefore, ellagic acid reduced the amount of ox-LDL-induced proliferation of RASMC via inactivation of the ERK pathway and suppression of PCNA expression. These results may significantly advance the understanding of the role that antioxidants play in the prevention of atherosclerosis.

Ellagic acid: Oxidised low-density lipoprotein: Rat aortic smooth muscle cell proliferation: Extracellular signal-regulated kinase 1/2: Proliferating cell nuclear antigen

Elevated plasma LDL has been implicated in the pathogenesis of atherosclerosis $^{(1)}$. Oxidised LDL (ox-LDL) stimulates the proliferation of aortic smooth muscle cells and the up regulation of extracellular signal-regulated kinases $(\mathrm{ERK})^{(2)}$. Therefore, the ox-LDL-induced proliferation of vascular smooth muscle cells (VSMC) in the intima of the arterial wall is believed to be a critical event in the development of atherosclerotic plaque.

Several studies have indicated that naturally occurring polyphenols can inhibit migration and proliferation of vascular cells ${ }^{(3,4)}$. Polyphenols found in green tea have been shown to inhibit LDL-induced human VSMC proliferation and to arrest endothelial cells in the G1 phase of the cell cycle ${ }^{(5)}$. Red wine polyphenols have also been found to decrease the proliferation and migration of VSMC by down regulating cyclin A expression and inactivating of the ERK pathway ${ }^{(3,6)}$.

The protein proliferating cell nuclear antigen (PCNA) has been implicated in a number of cellular processes, including DNA replication, DNA repair, and cell-cycle regulation ${ }^{(7-9)}$. It has also been reported that PCNA synthesis is strictly regulated during the cell cycle, and that there is a clear increase in PCNA protein during the G1/S transition. It is evident that PCNA represents a key protein necessary for the transition of cells from quiescence to the $S$ phase ${ }^{(10)}$.

Ellagic acid is a phenolic compound present in berries and nuts ${ }^{(11-13)}$. It has been found to have antioxidative properties and to inhibit LDL oxidation ${ }^{(14)}$. Our recent study also indicated that ellagic acid lowers oxidative stress and reduces atherosclerosis in hyperlipidaemic rabbits ${ }^{(15)}$.

We investigated the effect of ellagic acid on ox-LDLinduced proliferation of rat aortic smooth muscle cells (RASMC). We hypothesised that this effect is due to the activation of ERK 1/2 and the expression of cell-cycle regulatory protein PCNA.

\section{Materials and methods}

Isolation and preparation of oxidised low-density lipoprotein

LDL was isolated from normal human plasma by ultracentrifugation in the presence of EDTA $(1 \mathrm{mmol} / \mathrm{l})$ in a $\mathrm{KBr}$ gradient at $200000 \mathrm{~g}$ for $14 \mathrm{~h}$ at $4^{\circ} \mathrm{C}$. The LDL fraction was decanted and dialysed against three changes of $1500 \mathrm{ml}$ of $\mathrm{NaCl}(150 \mathrm{mmol} / \mathrm{l})$ and EDTA $(0.25 \mathrm{mmol} / \mathrm{l})$ at $\mathrm{pH} 7.4$. LDL was sterilised using $0.22 \mu \mathrm{m}$ Millipore filters and stored in the dark at $4^{\circ} \mathrm{C}$. Concentrations of LDL are given as $\mu \mathrm{g}$ LDL protein. LDL $(1-2 \mathrm{mg} / \mathrm{ml})$ was mildly oxidised at $37^{\circ} \mathrm{C}$ in the presence of $\mathrm{CuSO}_{4}$ at a final concentration of $5 \mu \mathrm{mol} / 1$ for $24 \mathrm{~h}$. The oxidation was terminated by the addition of EDTA $(1.0 \mathrm{mmol} / \mathrm{l})$. Ox-LDL fractions were dialysed against PBS with EDTA $(0.1 \mathrm{mmol} / \mathrm{l})$. The purity

Abbreviations: ERK, extracellular signal-regulated kinase; MTT, 3-[4,5-dimethylthiazol-2-yl]-2,5-diphenyl-terazolium; ox-LDL, oxidised LDL; PCNA, proliferating cell nuclear antigen; RASMC, rat aortic smooth muscle cell; VSMC, vascular smooth muscle cell.

* Corresponding author: Dr Weng-Cheng Chang, fax +886 42247 8536, email winstonwcchang@hotmail.com 
and the extent of the oxidation of LDL were determined by the formation of thiobarbituric acid reactive products according to the method of Ohkawa et al. with minor modifications ${ }^{(16)}$

\section{Cell culture and measurement of cell viability}

Rat thoracic aortic smooth muscle cells (RASMC) were obtained from the National Health Research Institute, and cultured in Dulbecco's modified Eagle medium (Gibco, Carlsbad, CA, USA) at $37^{\circ} \mathrm{C}$ in a humidified incubator with an atmosphere of $95 \%$ air and $5 \% \mathrm{CO}_{2}$. Cells were subcultured into a ninety-six well plate with $1 \times 10^{4}$ cells per well in $100 \mu \mathrm{l}$ RPMI-1640 medium (Sigma, St Louis, MO, USA) and then treated with ox-LDL $(100 \mu \mathrm{g} / \mathrm{ml})$, with or without ellagic acid $(50 \mu \mathrm{mol} / \mathrm{l})$ for $24 \mathrm{~h}$. All subcultures were done in triplicate. At the end of the incubation period, the cells were harvested and washed with PBS. Then, $10 \mu \mathrm{l}$ of 3-[4,5-dimethylthiazol-2yl]-2,5-diphenyl-terazolium (MTT) (Sigma) were added to the cells and incubated for $3 \mathrm{~h}$ at $37^{\circ} \mathrm{C}$. The cells were then incubated overnight with $100 \mu$ l solution buffer $(10 \%$ $\mathrm{SDS} ; \mathrm{HCl}(0.01 \mathrm{~mol} / \mathrm{l}))$. The absorbance was measured on an ELISA reader (Multiskan EX; Labsystems, Helsinki, Finland) at a test wavelength of $570 \mathrm{~nm}$, and a reference wavelength of $650 \mathrm{~nm}^{(17)}$.

\section{Cell-cycle analysis}

Cellular DNA contents were measured by flow cytometry as described previously ${ }^{(18)}$ in order to estimate the proportion of RASMC in different phases of the cell cycle affected by ellagic acid. Approximately $5 \times 10^{5}$ cells/well of subcultured cells, which had been treated with or without ellagic acid, were harvested by centrifugation. They were fixed with $70 \%$ ethanol on ice before being stored at $4^{\circ} \mathrm{C}$ overnight. The next day, the cells were finally re-suspended in PBS containing propidium iodide $(40 \mu \mathrm{g} / \mathrm{ml})$ andRNase $(0.1 \mathrm{mg} / \mathrm{ml}$; Sigma, St Louis, MO, USA), and $5 \%$ triton X-100 (Amresco, Inc., Solon, OH, USA) for $30 \mathrm{~min}$ at $37^{\circ} \mathrm{C}$. Cells were then analysed in a flow cytometer (Becton-Dickinson, San Jose, CA, USA) equipped with an $\mathrm{Ar}$ ion laser at a wavelength of $488 \mathrm{~nm}$ in order to determine the cell cycle.

Western blot analysis of extracellular signal-regulated kinase $1 / 2$ and proliferating cell nuclear antigen expression

The expression of ERK 1/2 and PCNA was measured by Western blot analysis with a commercially available kit using rabbit polyclonal anti-p-ERK 1/2 mitogen-activated protein kinases and anti-PCNA primary antibodies (Abcam, Cambridge, Cambs, UK) ${ }^{(5,19)}$. RASMC were stimulated with ox-LDL $(100 \mu \mathrm{g} / \mathrm{ml})$ for $10 \mathrm{~min}$ after pretreatment with ellagic acid $(50 \mu \mathrm{mol} / \mathrm{l})$ for $24 \mathrm{~h}$. The experiments were terminated by rinsing the cells with PBS. After lysis of the cells, $\beta$-actin, phosphorylated ERK $1 / 2$ and PCNA were extracted according to the manufacturer's instructions. The blots were subsequently incubated with the desired primary antibody. A Zero-D scan ${ }^{\mathrm{TM}}$ (Scanalytics, Inc. (BD Biosciences Bioimaging), Rockville, MD, USA) was used for densitometric

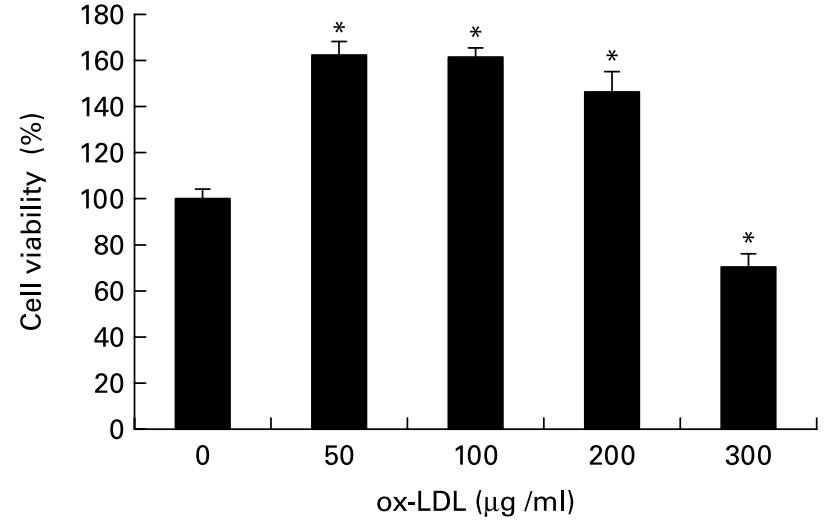

Fig. 1. Effects of different concentrations of oxidised LDL (ox-LDL) on rat aortic smooth muscle cells (RASMC) viability assayed by the 3-[4,5-dimethylthiazol-2-yl]-2,5-diphenyl-terazolium test. RASMC were treated with increasing concentrations $(50-300 \mu \mathrm{g} / \mathrm{ml})$ of ox-LDL for $24 \mathrm{~h}$ in $1 \%$ fetal bovine serum- Dulbecco's modified Eagle medium. Results were from three experiments each and each was performed in triplicate. Values are means, with their standard errors represented by vertical bars. * Mean value was significantly different to that of the control group $(P<0.05)$.

quantification. The $\beta$-actin was used for normalisation of protein expression.

\section{Statistical analysis}

All data are expressed as mean values with their standard errors. Comparisons between the four groups were made by one-way ANOVA. Tukey's post hoc test was used to analyse significant effects. A $P$ value of 0.05 was taken as the threshold for statistical significance.

\section{Results}

The effect of ellagic acid on the viability of rat aortic smooth muscle cells

Cell viability was assayed by the MTT test. After $24 \mathrm{~h}$ incubation with $0 \cdot 1,10,50$, and $100 \mu \mathrm{M}$-ellagic acid, cell

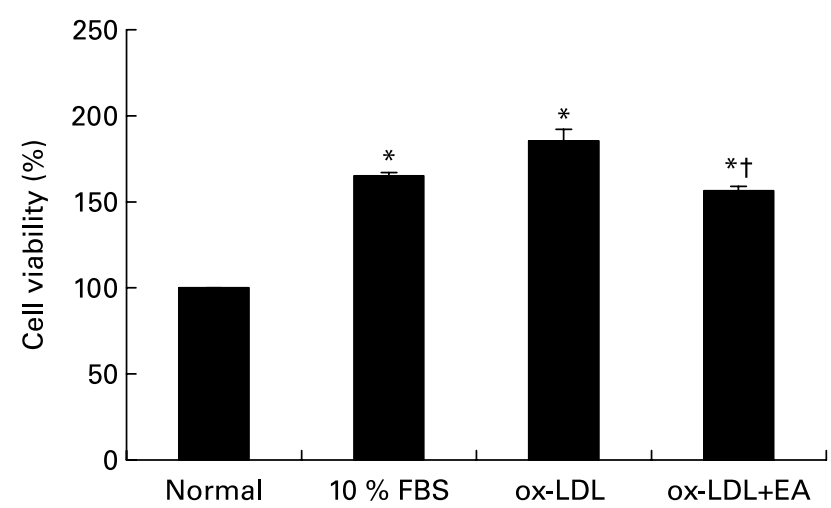

Fig. 2. Effect of ellagic acid (EA) on oxidised LDL (ox-LDL)-induced proliferation of rat aortic smooth muscle cells (RASMC). RASMC were incubated with ox-LDL $(100 \mu \mathrm{g} / \mathrm{ml})$ alone or with $50 \mu \mathrm{M}$-ellagic acid for $24 \mathrm{~h}$ in $0.1 \%$ fetal bovine serum (FBS)-Dulbecco's modified Eagle medium. Values are means ( $n 3)$, with their standard errors represented by vertical bars. * Mean value was significantly different to that of the normal group $(P<0.05)$. $†$ Mean value was significantly different to that of the ox-LDL group $(P<0.05)$. 

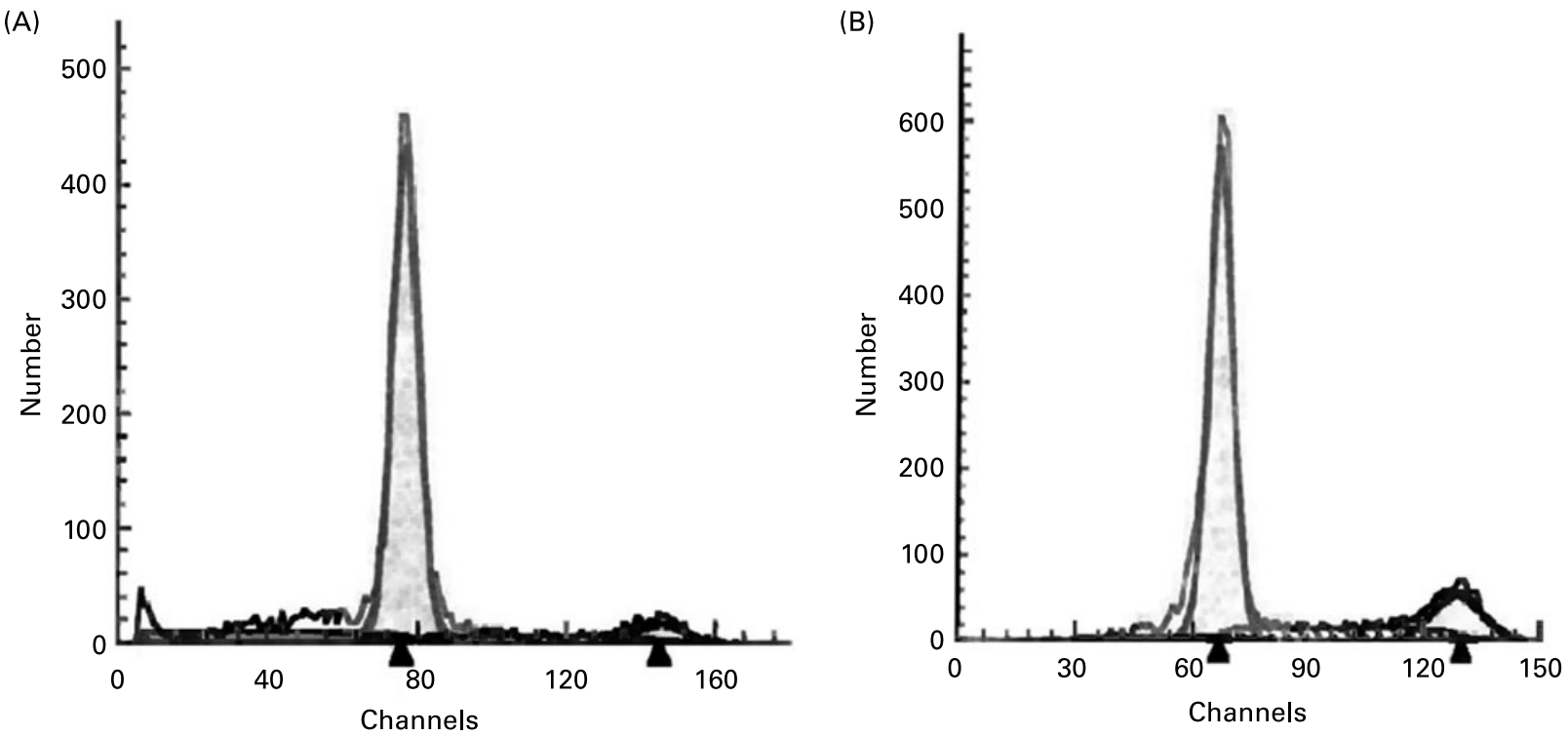

(C)

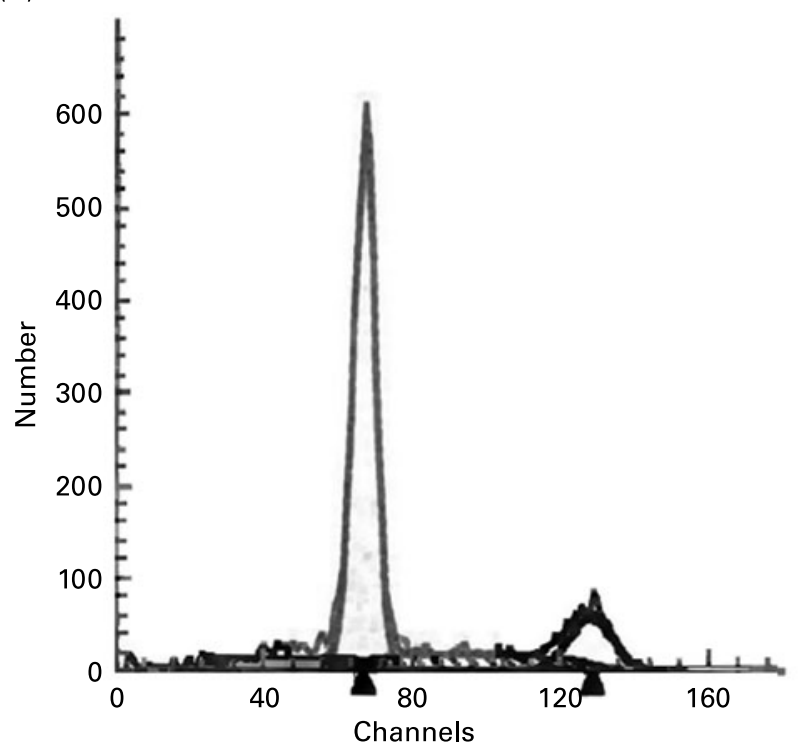

(D)

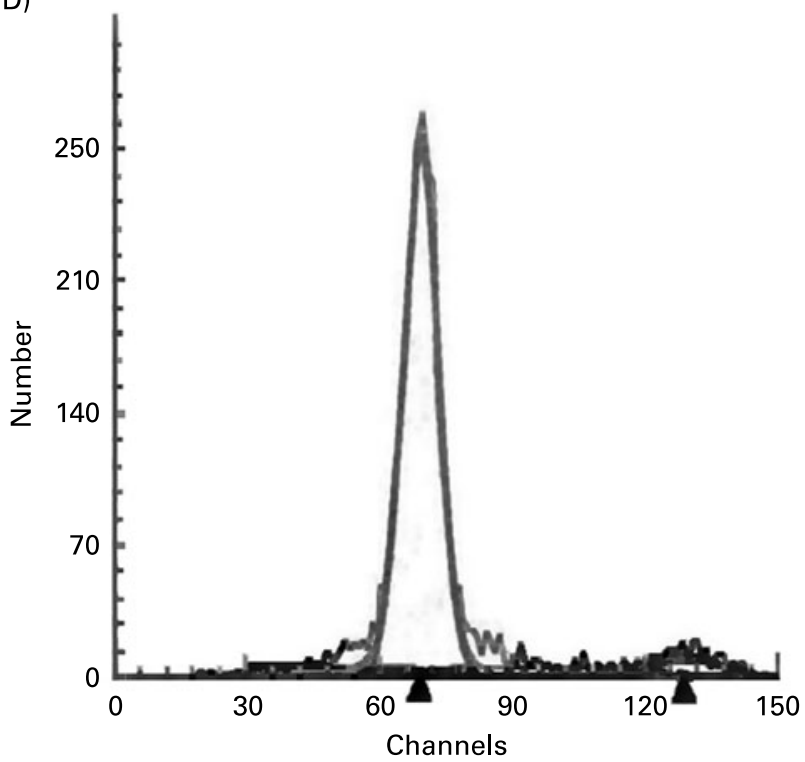

Fig. 3. Effect of ellagic acid (EA) on rat aortic smooth muscle cells (RASMC) cell cycle induced by oxidised LDL (ox-LDL). RASMC were incubated with ox-LDL $(100 \mu \mathrm{g} / \mathrm{ml})$ alone or with $50 \mu \mathrm{M}-\mathrm{EA}$ for $24 \mathrm{~h}$ in $1 \%$ fetal bovine serum (FBS)-Dulbecco's modified Eagle medium. (A) Normal cells - G0/G1, $86.86 \%$; G2/M, $6.38 \%$; S, 7.76\%. (B) $10 \%$ FBS-treated cells - G0/G1, 75.91\%; G2/M, 12.32\%; S, $11.7 \%$. (C) ox-LDL-treated cells - G0/G1, 71.01\%; G2/M, 13.57\%; S, $15.42 \%$. (D) Cells treated with ox-LDL and EA - G0/G1, 83.2\%; G2/M, 7.32\%; S, $9.4 \%$.

viability was, respectively, $106($ SEM $2 \cdot 2), 106 \cdot 4$ (SEM 2.8), 93.8 (SEM 2.8) and 39.4 (SEM 2.9) \% of control levels. Clearly, $100 \mu \mathrm{M}$-ellagic acid causes a significant reduction in cell viability.

Oxidised low-density lipoprotein-induced rat aortic smooth muscle cell proliferation

The effect of ox-LDL on the proliferation of RASMC was detected by MTT assay. As shown in Fig. 1, treatment with ox-LDL ( 50 to $200 \mu \mathrm{g} / \mathrm{ml}$ ) for $24 \mathrm{~h}$ resulted in increased cell viability; however, doses that exceeded $200 \mu \mathrm{g} / \mathrm{ml}$ had a cytotoxic effect.
Effect of ellagic acid on oxidised low-density lipoproteininduced proliferation of rat aortic smooth muscle cells

As shown in Fig. 2, stimulation of RASMC with ox-LDL $(100 \mu \mathrm{g} / \mathrm{ml})$ for $10 \mathrm{~min}$ resulted in increased cell viability. Pre-incubation of ox-LDL with ellagic acid ( $50 \mu \mathrm{mol} / \mathrm{l})$, however, significantly inhibited ox-LDL-induced cell viability.

Effect of ellagic acid on the rat aortic smooth muscle cell cycle and proliferating cell nuclear antigen expression

To clarify the effect of ellagic acid on cell-cycle regulation, we analysed the phases of cell cycle using flow cytometry. As shown in Fig. 3, the percentages of G2/M and $\mathrm{S}$ phase increased 
after stimulation of RASMC with ox-LDL and decreased after pre-treatment of ox-LDL with ellagic acid. Using Western blotting, we examined whether the effect of ellagic acid on the cell cycle was associated with the expression of PCNA (Fig. 4). The gene expression patterns were consistent with the cellcycle analysis data. Cells that had been treated with ox-LDL only increased in number in the $\mathrm{S}$ phase; this increase was accompanied by increasing the expression of PCNA. However, cells pre-treatment with ox-LDL and ellagic acid decreased in number with the $\mathrm{S}$ phase.

Effect of ellagic acid on extracellular signal-regulated kinase $1 / 2$ phosphorylation

Activation of ERK 1/2 was accompanied by phosphorylation of the Tyr204 residue. RASMC were stimulated with ox-LDL $(100 \mu \mathrm{g} / \mathrm{ml})$ for different periods of time; enhanced phosphorylation of ERK 1/2 occurred after cells had been exposed to ox-LDL for $5 \mathrm{~min}$, but then began to decline (Figs. 5 (A) and (B)). Compared with the control group ( $1 \%$ fetal bovine serum), exposure of RASMC to ox-LDL caused a marked increase in the phosphorylation of ERK 1/2. The ox-LDL-stimulated phosphorylation of ERK 1/2 was inhibited by ellagic acid (Fig. 6).

\section{Discussion}

The present study demonstrates that ellagic acid significantly inhibited ox-LDL-induced proliferation of RASMC perhaps by inactivating the ERK pathways and blocking cell-cycle

(A)
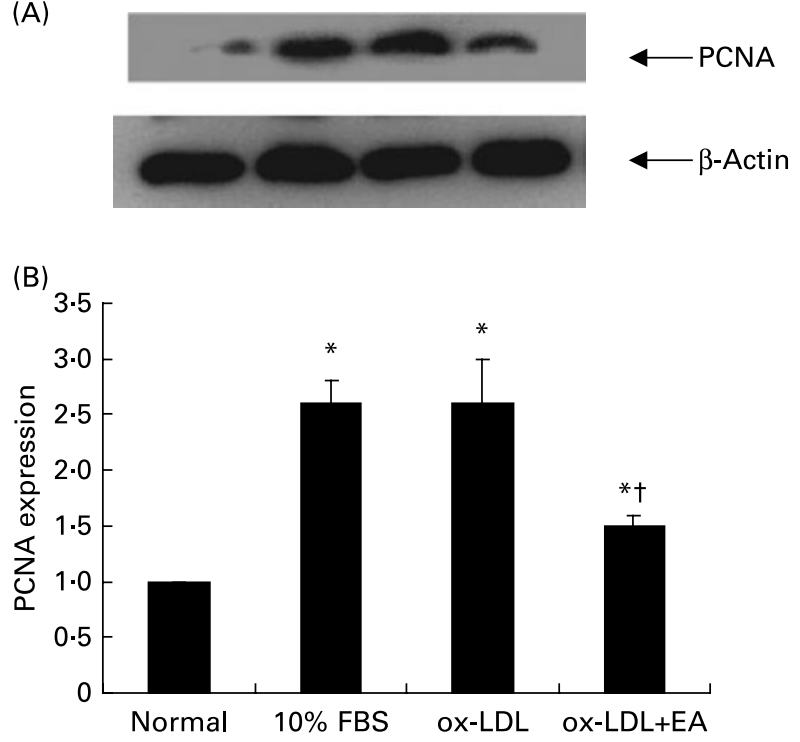

Fig. 4. Effects of ellagic acid (EA) on oxidised LDL (ox-LDL)-induced proteinproliferating cell nuclear antigen (PCNA) expression. (A) Western blot of PCNA. (B) PCNA expression as a ratio to the control. Rat aortic smooth muscle cells were incubated with ox-LDL $(100 \mu \mathrm{g} / \mathrm{ml})$ with or without $50 \mu \mathrm{M}$ EA for $24 \mathrm{~h}$ in $1 \%$ fetal bovine serum (FBS)-Dulbecco's modified Eagle medium. Proteins were extracted from the cells and analysed by Western blot analysis. The immunoblots shown are representative of three independent experiments. Values are means $(n 3)$, with their standard errors represented by vertical bars. * Mean value was significantly different to that of the normal group $(P<0.05)$. $†$ Mean value was significantly different to that of the ox-LDL group $(P<0.05)$.
(A)
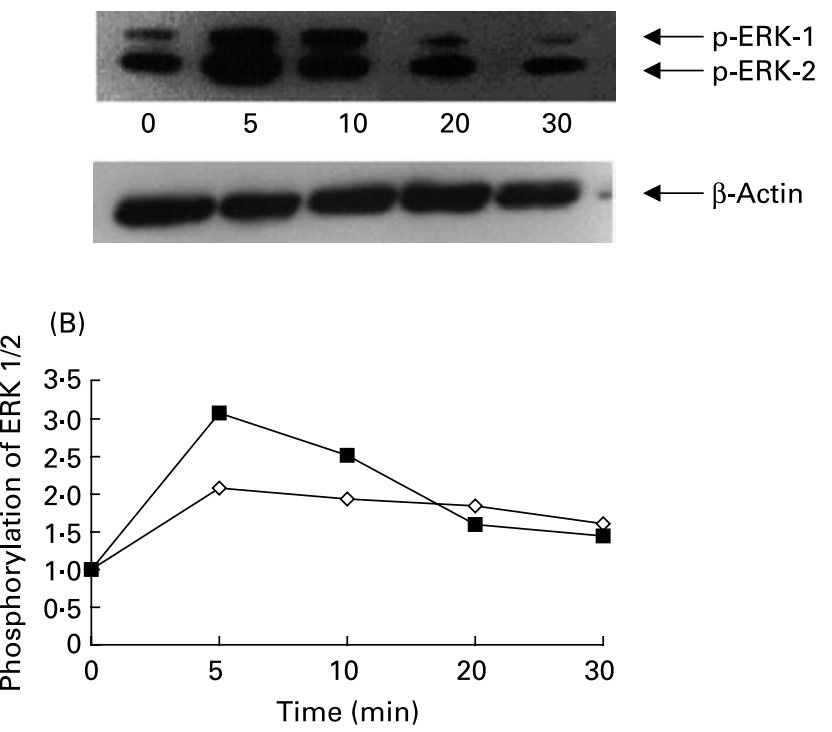

Fig. 5. Time course of oxidised LDL (ox-LDL)-induced phosphorylation of extracellular signal-regulated kinases (ERK) 1 and 2 in rat aortic smooth muscle cells (RASMC). (A) Western blot of phosphorylated ERK ( $p$-ERK) 1 and 2. (B) Phosphorylation of ERK $1(\diamond)$ and ERK $2(\square)$ expressed as a ratio to the control. Cells were cultured in twelve-well plates until confluence and then transferred to medium with serum-free medium for $24 \mathrm{~h}$. After $24 \mathrm{~h}$ cultivation, the RASMC were stimulated with ox-LDL $(100 \mu \mathrm{g} / \mathrm{ml})$ for the indicated time periods ( $0 \mathrm{~min}$ to $30 \mathrm{~min}$ ).

(A)
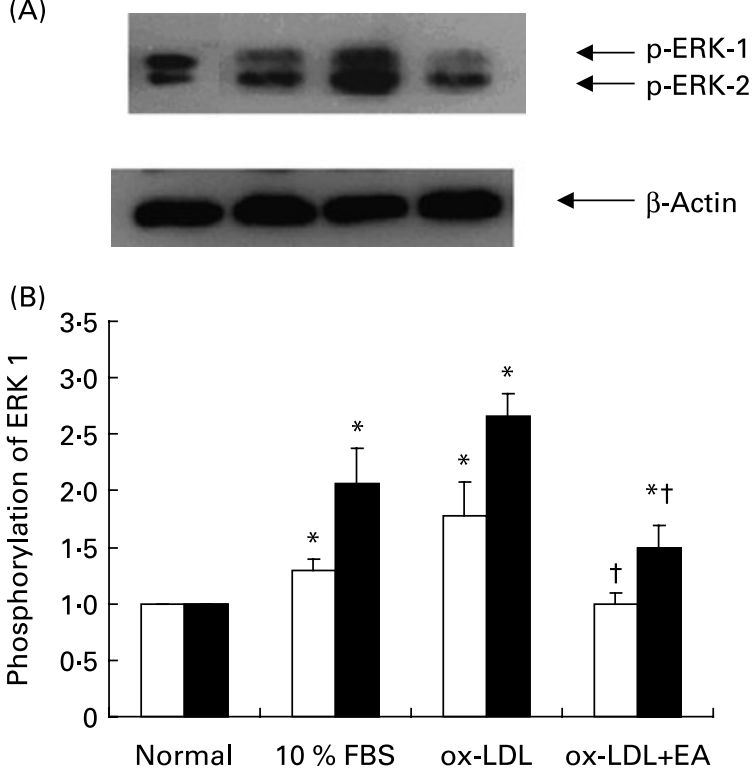

Fig. 6. Effects of ellagic acid (EA) on oxidised LDL (ox-LDL)-induced extracellular signal-regulated kinases (ERK) 1 and 2 phosphorylation. (A) Western blot of phosphorylated ERK (p-ERK) 1 and 2. (B) Phosphorylation of ERK 1 $(\square)$ and ERK 2 ( $\square$ ) expressed as a ratio to the control. Rat aortic smooth muscle cells were stimulated with ox-LDL $(100 \mu \mathrm{g} / \mathrm{ml})$ for $10 \mathrm{~min}$ after pretreatment with $50 \mu \mathrm{M}$-EA for $24 \mathrm{~h}$ in $1 \%$ fetal bovine serum (FBS)-Dulbecco's modified Eagle medium. Proteins were extracted from the cells and analysed by Western blot analysis. The immunoblots shown are representative of three independent experiments. Values are means $(n 3)$, with their standard errors represented by vertical bars. ${ }^{*}$ Mean value was significantly different to that of the normal group $(P<0.05)$. $†$ Mean value was significantly different to that of the ox-LDL group $(P<0.05)$. 
progression. Ellagic acid is a phenolic compound found in fruits including grape juice $(10.2 \mathrm{mg} / 100 \mathrm{~g})$, grape wine $(5.6 \mathrm{mg} / 100 \mathrm{~g})$, blueberries $(0.9 \mathrm{mg} / 100 \mathrm{~g})$, blackberries $(42.4 \mathrm{mg} / 100 \mathrm{~g})$, raspberries $(17.9 \mathrm{mg} / 100 \mathrm{~g})$ and strawberries $(19.8 \mathrm{mg} / 100 \mathrm{~g})^{(20)}$. The typical dietary intake of ellagic acid in humans is approximately $40-80 \mathrm{mg} / \mathrm{d}$ if $200 \mathrm{~g}$ strawberries or blackberries are eaten ${ }^{(20)}$. In the present study, we found that $50 \mu \mathrm{M}$-ellagic acid treatment effectively reduced ox-LDL-induced RASMC proliferation. Previous studies also indicated that other polyphenols, such as vitamin $\mathrm{E}$ $(50 \mu \mathrm{mol} / \mathrm{l})$ and resveratrol $(30-50 \mu \mathrm{mol} / \mathrm{l})$ also inhibited proliferation of $\operatorname{VSMC}^{(6,21)}$. This dose $(50 \mu \mathrm{mol} / \mathrm{l})$ of ellagic acid is equivalent to the dietary intake of approximate $200 \mathrm{~g}$ of berries subject to absorption ${ }^{(20-23)}$.

Increased proliferation of intimal VSMC is an important component in the development of atherosclerosis, and ox-LDL is a mitogen for $\operatorname{VSMC}^{(2)}$. In the present study, we found that ox-LDL induced RASMC proliferation. Ox-LDL at low concentrations $(0-100 \mu \mathrm{g} / \mathrm{ml})$ increased cell viability in a dose-dependent manner; however, ox-LDL at doses of $200 \mu \mathrm{g} / \mathrm{ml}$ began to elicit a cytotoxic effect. This finding of ox-LDL exhibiting a biphasic effect on VSMC is similar to that reported by other researchers; low concentrations $(20-120 \mu \mathrm{g} / \mathrm{ml})$ had a proliferative effect while high doses $(>200 \mu \mathrm{g} / \mathrm{ml})$ had a cytotoxic effect ${ }^{(6,24,25)}$. The increased mitogenic effect of ox-LDL is attributed to the chemical changes brought about by the process of oxidation of LDL components such as the generation of $\mathrm{H}_{2} \mathrm{O}_{2}$, and the conversion of phosphatidylcholine to lysophosphatidylcholine and 4-hydroxy-2-nonenal ${ }^{(26,27)}$. In addition, certain oxidation products of unsaturated NEFA have been shown to stimulate mitogenic signalling pathways in VSMC ${ }^{(28)}$.

Previous studies have indicated that ox-LDL stimulates VSMC proliferation via activation of the ERK pathway ${ }^{(2)}$. It is known that the ERK pathway is activated by oxidative stress. Liu et al. postulated that ox-LDL might induce a response to oxidative stress by stimulating the generation of intracellular reactive oxygen species ${ }^{(6)}$. Previous study also indicated that reactive oxygen species are able to induce tyrosine phosphorylation of mitogen-activated protein kinases and cell growth ${ }^{(29)}$. The present results indicated that treatment with ox-LDL significantly increased in cell proliferation and activation of ERK 1/2.

Our previous study found that ellagic acid exhibits free-radical scavenging activities and reduces oxidative stress in cell and animal models ${ }^{(15,30)}$. We proposed that the inhibitory effect of ellagic acid on ox-LDL-induced cell proliferation might be due to its antioxidative ability. It might decrease reactive oxygen species production induced by ox-LDL and therefore inhibit ERK 1/2 expression.

PCNA synthesis is strictly regulated during the cell cycle and its protein is necessary for the transition of cells from quiescence to the $S$ phase ${ }^{(10)}$. In the present study, we found that the amount of PCNA in the G2/M and S phases increased after treatment of ox-LDL but decreased after prior addition of ellagic acid to the ox-LDL (Fig. 3). The amount of PCNA protein was consistent with the cell-cycle analysis data (Fig. 4). It is therefore likely that ellagic acid reduced ox-LDL-induced RASMC proliferation by suppressing PCNA transcription.

In conclusion, cell proliferation stimulated by ox-LDL was inhibited by ellagic acid according to the MTT test and G0/G1 cell-cycle arrest in smooth muscle cells. The expressions of ERK $1 / 2$ and PCNA were also suppressed by ellagic acid. Therefore, ellagic acid inhibits ox-LDL-induced aortic smooth muscle cell proliferation by inactivating the ERK 1/2 pathway and by suppressing the expression of PCNA. These results may advance the understanding of the role of antioxidants in the prevention of atherosclerosis.

\section{Acknowledgements}

The research was supported by grants from the National Science Council, Taiwan (NSC93-2320-B-039-017).

\section{References}

1. Gotto AM (1992) Therapeutic interventions for hypercholesterolemia. Clin Cardiol 15, Suppl. 3, 11118-11121.

2. Yang CM, Chien CS, Hsiao LD, Pan SL, Wang CC, Chiu CT \& Lin CC (2001) Mitogenic effect of oxidized low-density lipoprotein on vascular smooth muscle cells mediated by activation of Ras/Ras/MEK/MAPK pathway. $\mathrm{Br} J$ Pharmacol 132, $1531-1541$.

3. Iijima K, Yoshizumi M, Hashimoto M, et al. (2002) Red wine polyphenols inhibit vascular smooth muscle cell migration through two distinct signaling pathways. Circulation 105, 2404-2410.

4. Paper DH (1998) Natural products as angiogenesis inhibitors. Planta Medica 64, 686-695.

5. Locher R, Emmanuele L, Suter PM, Vetter W \& Barton M (2002) Green tea polyphenols inhibit human vascular smooth muscle cell proliferation stimulated by native low-density lipoprotein. Eur J Pharmacol 434, 1-7.

6. Liu Y \& Liu G (2004) Isorhapontigenin and resveratrol suppress ox-LDL-induced proliferation and activation of ERK 1/2 mitogen-activated protein kinases of bovine aortic smooth muscle cells. Biochem Pharmacol 67, 777-785.

7. Krishna TSR, Kong XP, Gary S, Burgers PM \& Kuriyan J (1994) Crystal structure of the eukaryotic DNA polymerase processivity factor PCNA. Cell 79, 1233-1243.

8. Shivji MKK, Kenny MK \& Wood RD (1992) Proliferating cell nuclear antigen is required for DNA excision repair. Cell 69 , $367-374$.

9. Waga S, Hannon GJ, Beach D \& Stillman B (1994) The p21 inhibitor of cyclin-dependent kinase controls DNS replication by interaction with PCNA. Nature 369, 574-578.

10. Morris GF \& Mathews MB (1989) Regulation of proliferating cell nuclear antigen during the cell cycle. J Biol Chem 264, 13856-13864.

11. Sellappan S, Akoh CC \& Krewer G (2002) Phenolic compounds and antioxidant capacity of Georgia-grown blueberries \& blackberries. J Agric Food Chem 50, 2432-2438.

12. Anderson KJ, Teuber SS, Gobeille A, Cremin P, Waterhouse AL \& Steinberg FM (2001) Walnut polyphenolics inhibit in vitro human plasma and LDL oxidation. $J$ Nutr 131, 2837-2842.

13. de Ancos B, Gonzalez EM \& Cano MP (2000) Ellagic acid, vitamin $\mathrm{C}$ and total phenolic contents and radical scavenging capacity affected by freezing and frozen storage in raspberry fruit. J Agric Food Chem 48, 4565-4570.

14. Priyadarsini KI, Khopde SM, Kumar SS \& Mohan H (2002) Free radical studies of ellagic acid, a natural phenolic antioxidant. J Agric Food Chem 50, 2200-2206.

15. Yu YM, Chang WC, Wu CH \& Chiang SY (2005) Reduction of oxidative stress and apoptosis in hyperlipidemic rabbits by ellagic acid. J Nutr Biochem 16, 675-681. 
16. Ohkawa H, Ohishi N \& Yagi K (1979) Assay for lipid peroxides in animal tissues by thiobarbituric acid reaction. Anal Biochem 95, 351-358.

17. Lee E \& Surh YJ (1998) Induction of apoptosis in HL-60 cells by pungent vaniloids, [6]-paradol. Cancer Lett 134, 163-168.

18. Chen HC, Hsieh WT, Chang WC \& Chung JG (2004) Aloeemodin induced in vitro G2/M arrest of cell cycle in human promyelocytic leukemia HL-60 cells. Food Chem Toxicol 42, $1251-1257$.

19. Murakami-Nakai C, Maeda N, Yonezawa Y, Kuriyama I, Kamisuki S, Takahashi S, Sugawara F, Yoshida H, Sakaguchi K \& Mizushina Y (2004) The effects of dehydroaltenusin, a novel mammalian DNA polymerase $\alpha$ inhibitor, on cell proliferation and cell cycle progression. Biochim Biophys Acta 1676, 193-199.

20. Mertens-Talcott SU, Talcott ST \& Percival SS (2003) Low concentrations of quercetin and ellagic acid synergistically influence proliferation, cytotoxicity and apoptosis in MOLT-4 human leukemia cells. J Nutr 133, 2669-2674.

21. Chai YC, Binion DG \& Chisolm GM (2000) Relationship of molecular structure to the mechanism of lysophospholipidinduced smooth muscle cell proliferation. Am J Physiol Heart Circ Physiol 279, H1830-H1838.

22. Walgren RA, Walle UK \& Walle T (1998) Transport of quercetin and its glucosides across human intestinal epithelial Caco-2 cells. Biochem Pharmacol 55, 1721-1727.

23. Whitley AC, Stoner GD, Darby MV \& Walle T (2003) Intestinal epithelial cell accumulation of the cancer preventive polyphenol ellagic acid - extensive binding to protein and DNA. Biochem Pharmacol 66, 907-915.

24. Auge N, Pieraggi MT, Thiers J \& Negre-Salvayre R (1995) Proliferation and cytotoxic effects of mildly oxidized lowdensity lipoproteins on vascular smooth muscle cells. Biochem J 309, 1015-1020.

25. Chatterjee S (1992) Role of oxidized human plasma low-density lipoproteins in atherosclerosis: effects on smooth muscle cell proliferation. Mol Cell Biochem 111, 143-147.

26. Stiko A, Regnstrom J, Shah PK, Cercek B \& Nilsson J (1996) Active oxygen species and lysophosphatidylcholine are involved in oxidized low-density lipoprotein activation of smooth muscle cell DNA synthesis. Arterioscler Throm Vasc Biol 16, 194-200.

27. Reuf J, Rao GN, Li F, Bode C, Patterson C, Bhatnagar A \& Runge MS (1998) Induction of rat aortic smooth muscle cell growth by the lipid peroxidation product 4-hydroxy-2-nonenal. Circulation 1997, 1071-1078.

28. Rao GN, Alexander RW \& Runge MS (1995) Linoleic acid and its metabolites, hydroperoxyoctadecadienoic acids, stimulate c-fos, c-Jun, and c-Myc mRNA expression, mitogen-activated protein kinase activation, and growth in rat aortic smooth muscle cells. J Clin Invest 1996, 842-847.

29. Baas AS \& Berk BC (1995) Differential activation of mitogenactivated protein kinases by $\mathrm{H}_{2} \mathrm{O}_{2}$ and $\mathrm{O}_{2}^{-}$in vascular smooth muscle cells. Circ Res 1977, 2936-2942.

30. Yu YM, Wang ZH, Liu CH \& Chen CS (2006) Ellagic acid inhibits IL-1 $\beta$-induced cell adhesion molecule expression in human umbilical vein endothelial cells. Br J Nutr 97, 692-698. 